\title{
Spatial and Temporal Variation in Fine Root Biomass, Productivity and Turnover in Shorea Robusta Along the Gradient of Tree Girth Size
}

\section{Rachita Pandey}

Kumaun University

Surendra Singh Bargali ( $\square$ surendrakiran@rediffmail.com )

Kumaun University https://orcid.org/0000-0001-6341-0945

Kiran Bargali

Kumaun University

\section{Research Article}

Keywords: Tree biomass, Fine root biomass (FRB), Fine root production (FRP), Fine root turnover (FRT), Soil depth

Posted Date: September 30th, 2021

DOl: https://doi.org/10.21203/rs.3.rs-930732/v1

License: (1) This work is licensed under a Creative Commons Attribution 4.0 International License. Read Full License 


\section{Abstract}

Fine roots ( $\leq 2 \mathrm{~mm}$ of diameter) contribute diminutive fractions of the overall tree biomass but are highly zestful and functionally remarkable component for assessing forest carbon and nutrient budgets. This study assessed how tree girth influenced fine root biomass (FRB), production (FRP) and turnover rate (FRT) in sub tropical sal forest.Four sites (S1, S2, S3, S4) were established in the bhabhar region of Nainital district, Uttarakhand, India within an elevational range of $405 \mathrm{~m}$ and $580 \mathrm{~m}$. On the basis of girth size, sal trees were categorized in five girth size classes. Fine roots were sampled seasonally to a depth of $60 \mathrm{~cm}$ and divided into 3 layers (0-20, 20-40 and 40-60 cm).FRB was significantly affected by tree girth size $(p<0.05)$ while FRP and FRT showed insignificant effect. FRB was higher in lower girth classes $(A-C)$ as compared to higher girth classes (D-E).Seasonal variation of FRB in all girth sizes showed a keen resemblance as the standing FRB reached pinnacle during rainy season and reached bottom-line in the winter season. Maximum FRB was reported for uppermost organo-mineralic soil depth $(0-20 \mathrm{~cm})$ at $1 \mathrm{~m}$ distance from tree bole and decreased with increasing soil depth and distance from tree bole while FRT showed a reverse trend. The present study will provide a holistic outlook on variations in FRB, FRP and FRT and the impact of edaphic characteristics and tree girth on fine root dynamics with respect to the studied forest stands.

\section{Introduction}

Fine roots ( $\leq 2 \mathrm{~mm}$ of diameter) represent an indispensable component of belowground ecological processes which substantially contributes to forest biogeochemical cycling. Plant growth, competition and belowground carbon and nutrient dynamics are greatly influenced by root lifespan (Anderson et al. 2003). In forest ecosystems, fine roots also serve as a pre-eminent sink for the carbon seized by leaves (Vogt et al. 1996). Fine roots are tremendously influenced by changing environmental conditions such as wavering regimes of temperature (Majdi and Ohrvik, 2004) moisture content of the soil (Konopka et al. 2007) nitrogen availability in the soil (Noguchi et al. 2013). Forest soils are immensely affected by fine roots as they put forth a pronounced impact on the accumulated organic matter of the soil after death and decay and also influence the development of soil profile (Persson, 1983; Garkoti, 2011). The swift rate of fine root mortality and turnover significantly contributes to the nutrient and carbon exchange between plant and soil carbon as a consequence has a major impact on forest biogeochemical cycling (Kaushal et al. 2019).

Young roots have strong tendency to acquire water and nutrients at high rate, while the older roots have low respiratory rate and nutrient absorption capacity (Baldi et al. 2010). In case of tree seedlings, mature roots have larger surface area thus contribute more in total nutrient uptake in comparison to younger roots (Hawkins et al. 2014).Fine roots are often abundant in upper soil horizons and decreases towards deeper horizons due to abundance of nutrients, bulk of organic matter and higher nitrogen contents and higher microbial activity in the superficial layer of soil (Meinen et al. 2009). Soil fertility is tremendously influenced by the vegetation cover, composition of soil and microbial communities inhabiting the soil and by the composition of litter and other organic aggregates which ultimately contribute to soil properties. (Bargali, 1996; Bargali et al. 2018).

The short term lifespan of roots in comparison to coarse roots, thus changing environmental conditions and seasons have a vast impact on their biomass. The fine roots present in superficial layers are higher in quantity and mostly contribute to FRB, FRP and decomposition while the fine roots present in deeper depths, which are usually less abundant play a crucial role in acquisition of water during the conditions of water scarcity. Geo-spatial fluctuations of FRB at site level are more prominent than seasonal variations (Yuan and Chen, 2013). Prevailingly, the fine root biomass depends on soil, site and stand properties and the organic matter dynamics of the soil determines the distribution of fine root biomass in the soil (Curt et al. 2001). Fine roots with a very short lifespan (high turnover rate) and slow decomposition rate contributes immensely to the accumulation of soil organic carbon ( Kramer et al. 2010). Fine root production is a key factor that regulates global forest carbon balance and the fine root standing crop which refers to the total fine root portion available for the resource acquisition at a particular time is determined by establishing a proper balance between the production and mortality of fine roots.

The subtropical Shiwalik sal (Shorea robusta Gaertn.) forests are regions of prime economic and ecological importance in the North West Himalayas of Uttarakhand state which exists in association with dry, moist mixed deciduous forests in the subtropical and tropical zone (Raizada et al. 2013).The primary forest vegetation chiefly comprises of trees, shrubs and herbs. Sal (Shorea robusta) is one of the climax and key timber yielding tree species of southern and eastern Asia including India. It is extensively dispersed in tropical and sub tropical forests of Northern and Central Himalayan foothills up to an elevation of approx. 1000m (Singh and Singh 1992;). Trees serve as a chief component of an ecosystem and play a crucial role in controlling and managing microclimatic conditions by directly or indirectly regulating the soil physical attributes, chemistry and biological properties (Bargali et al. 2019).

The fine root biomass and production are the key determinants of plant nutrient availability, acquisition and biogeochemical cycles in forest ecosystems (Schmid and Kazda, 2002), but despite the substantial impact of fine-roots in ecological processes, knowledge on the role of fine roots in biogeochemical cycling is scarce and the data are still inadequately represented both at national and international 
levels (Zhiyanski, 2014). The ecosystems for which belowground data are available are scarce in number in comparison to existing databases for aboveground components (Vogt et al. 1996). Several studies conducted on tree root systems and fine root biomass (Zhiyanski, 2003a; Lyubenova, 2009) provided useful information, the data on sal forests of Central Himalaya, India are limited. This study present result of an ingrowth study of how four major factors viz. season, depth, distance from tree bole and girth size affected the fine root dynamics in subtropical sal forest of Central Himalaya, India. More specifically this study demonstrated (a) Distribution and seasonal variation in fine root biomass of sal forest among different tree girth classes; (b) The variations in fine root production and turnover rate along girth size and (c) Responses of fine root parameters to soil characteristics.

\section{Methodology}

\section{Site description and Climate of the studied area}

Permanent plots of 1 ha were established at four experimental sites (S1, S2, S3 and S4) in Shorea robusta Gaertner $f$. forest growing in subtropical zone of bhabhar region in the Nainital district, Central Himalaya, India (Fig.1). A complete description of the study sites is provided in Table 1.

Climatically, the study sites lies within sub-tropical zone which is characterized by distinct seasonality throughout the year. The year comprises of three distinct seasons including dry summer (March- June) followed by warm and humid rainy season (July -September) and winter season which is cold (November-February). October is as a transitional month between rainy and winter season and the months of June to August constitute more than $90 \%$ of the annual rainfall (Fig. 2).

\section{Soil Sampling}

The soil samples were gathered randomly upto a depth of $60 \mathrm{~cm}$ in three soil depths $(0-20 \mathrm{~cm}, 20-40 \mathrm{~cm}$ and $40-60 \mathrm{~cm})$ in three seasons (rainy, winter and summer) using a soil corer. Sieves having different mesh sizes were used to determine soil texture (Indian Standard 1965). Soil pH (Jackson 1958) was recorded using a digital pH meter, bulk density was determined following Black (1965) and water holding capacity was estimated following Piper (1950). Soil was dried at $60^{\circ} \mathrm{C}$ in oven and gravimetric soil moisture was determined (Misra 1968). Soil porosity was calculated following Kumar (2000). Rapid titration method (Walkley and Black 1934) was utilized to determine soil organic carbon and standard ecological method provided by Subbiah and Asija (1956) was used to determine soil total nitrogen.

\section{Fine root biomass Sampling}

At each site, on the basis of girth size, S. robusta trees were divided into five size classes $\{A(30-60 \mathrm{~cm}), B(60-90 \mathrm{~cm}), C(90-120 \mathrm{~cm}), D(120-$ $150 \mathrm{~cm}), E(\geq 150)\}$ and three individuals in each size class were marked for data collection. Sequential coring (soil core technique) was used to collect fine roots using a stainless steel core $(7.5 \mathrm{~cm}$ internal diameter $x 60 \mathrm{~cm}$ long) with a sharp edge which was driven into the soil using hammer for fine root biomass estimation. Modified ingrowth core method was utilized for estimation of FRP in which for the first time the roots were collected using a steel auger and the hole from a root core was lined with a 2 mm mesh (Inclusion growth nylon root net) \{Fahey \& Hughes 2004, Yang et al. 2004\}. A total of 540 soil core samples, taken during 2017-2018 were subsequently analyzed. A depth of $60 \mathrm{~cm}$ was considered for carrying out soil and fine root sampling, with collection of three samples at three depths (0-20, 20-40, 40-60). Sampling was done randomly following a sampling design at different distances and directions from the base of the tree bole where each tree is a centre point of each sampling plot seasonally for one year. $1 \mathrm{~m}$ and $1.5 \mathrm{~m}$ distances from the tree bole at different directions were considered as sampling points Fine roots were excavated from the nets at fixed time intervals the nets and holes were repacked using the root free soil after every collection and the respective holes were marked for identification. The holes were redugged every season for excavation of fine roots. Samples were collected and the holes were refilled with root- free soil.

The collected samples of individual cores were packed in bags and were taken to the lab to sort the fine roots. To separate organic matter from the soil, a sequence of sieves were utilized and living and dead roots were sorted by using hands on the basis of visual characteristics such as colour and texture (Vogt et al., 1996) followed by the oven drying of root samples for 48 hours at $60^{\circ} \mathrm{C}$. The root biomass is formed by the dry weight of living fine roots, while necromass stands for the dry mass of dead fine roots of studied tree species. The mean values for each season were estimated and the stock of FRB and FRP of studied species in 0-60cm soil depth was prepared for rainy, winter and summer season. Across all the seasons and the study sites total 60 trees were marked (15 trees from every site belonging to 5 girth classes) and a total of 360 cores were collected.

\section{Statistical Analysis}


The data were examined statistically to adjudge the impact of season, soil depth and forest, distance on FRB, FRP and FRT using SPSS 16.0. MS office 2013 was used to establish linear regressions for the data and the Pearson's correlation test was performed using Past3 statistical package.

\section{Results}

\section{Soil characteristics}

Soil physical and chemical parameters are presented in Table 2. Bulk density varied from 1.06 to $1.44 \mathrm{~g} \mathrm{~cm}^{-3}$ and soil porosity ranged between $44.69 \%$ and $59.15 \%$ across the experimental sites. Bulk density increased with increasing soil depth while porosity decreased. Soil texture was reported as clay loam or loams at all the four sites. Soil pH varied significantly between the sites (5.31 and 7.67) and was slightly acidic in nature in S1 and S4 and slightly basic in nature in S2 and S3. Soil moisture ranged from $8.36 \%$ to $16.09 \%$ and was generally higher in deeper layers. Soil organic carbon was recorded maximum in S4 (2.87\%) and minimum in S1 (1.20\%) while no clear pattern was recorded across depths. Total nitrogen was recorded lowest at site S1 $(0.12 \%)$ and highest in site S4 $(0.28 \%)$ and decreased with increasing soil depth. $\mathrm{C} / \mathrm{N}$ ratio ranged between 5.06 and 11.93 across the sites.

\section{Fine root biomass (FRB)}

Significant differences were observed in FRB with respect to sites, seasons, size class and soil depth $(p<0.05)$ while the alterations in FRB with respect to distance from stem base was insignificant [Table 3(a)]. Paired $t$-test also showed marked differences in FRB among all the observed parameters [Table 3(b)].

\section{Spatial pattern in fine root biomass (FRB)}

Across the sites FRB ranged between $160.37 \pm 16.12 \mathrm{~kg} \mathrm{ha}^{-1}$ and $1195 \pm 27.61 \mathrm{~kg} \mathrm{ha}^{-1}$ in uppermost $(0-20 \mathrm{~cm})$ layer, $122.63 \pm 9.98$ and $785.42 \pm 53.03 \mathrm{~kg} \mathrm{ha}^{-1}$ in middle $(20-40 \mathrm{~cm})$ layer and $77.35 \pm 8.22 \mathrm{~kg} \mathrm{ha}^{-1}$ and $454.31 \pm 68.43 \mathrm{~kg} \mathrm{ha}^{-1}$ in deepest $(40-60 \mathrm{~cm})$ soil layer. At each site, maximum FRB was recorded in uppermost soil (organo-mineralic soil) layer $(0-20 \mathrm{~cm}$ ) and decreased towards deeper soil depth (Fig 3). FRB also recorded a decreasing pattern with increasing distance from tree bole with maximum FRB at $1 \mathrm{~m}$ distance (Table 3). Two way ANOVA revealed that there existed a significant disssimilarity between the depths $(F=71.58)$ at 0.05 level of significance while among distances the difference was insignificant $(F=1.03)$.

\section{Seasonal pattern in fine root biomass}

Seasonal fluctuation in the FRB is presented in Fig 3. At each site, highest peak of FRB $\left(1195 \pm 27.61 \mathrm{~kg} \mathrm{ha}^{-1}\right.$ in S1, $1012 \pm 64.95 \mathrm{~kg} \mathrm{ha}^{-1} \mathrm{in}$ $\mathrm{S} 2,475 \pm 16.51 \mathrm{~kg} \mathrm{ha}^{-1}$ in S3, $1111.44 \pm 64.24 \mathrm{~kg} \mathrm{ha}^{-1}$ in S4 site) was recorded during rainy season followed by summer and winter season. Two way ANOVA revealed that there existed a remarkable difference among the seasons $(F=197.86)$ at 0.05 level of significance.

\section{Tree size effect on FRB}

Higher FRB was recorded among the younger size classes A (30-60) to C (60-90cm) as compared to mature or old size classes (Fig. 3) across the tree size gradient. Maximum FRB was recorded for size class C at S1 and S3 sites which is about $22 \%$ and $25 \%$ of the total FRB. At S2 and S4 site maximum FRB was estimated for size class A with $27 \%$ and $25 \%$ contribution of the total FRB, respectively (Fig.4).Tree size significantly $(F=7.21 ; p<0.05)$ affected fine root biomass in $S$. robusta (Table 3a).

\section{Fine root production}

The annual FRP ranged between (488.08-2483.60 $\left.\mathrm{kg} \mathrm{ha}^{-1} \mathrm{yr}^{-1}\right)$ across the experimental sites. In all the sites, maximum annual FRP was recorded for uppermost soil layer and declined with escalating soil depth. In most of the experimental sites, FRP reached pinnacle for girth classes A, B or C representing younger trees and subsequently decreased in the higher size classes (Fig.5). Among all the size classes, the medium size class (C) was recorded to be most productive possibly due to more efficient use and allocation of nutrients and high metabolic rates in comparison to mature trees belonging to higher girth classes. At $1.5 \mathrm{~m}$ distance from the tree base maximum FRP was reported for girth class $\mathrm{C}\left(2483.60 \mathrm{~kg} \mathrm{ha}^{-1} \mathrm{yr}^{-1}\right)$ and at $1 \mathrm{~m}$ distance it was maximum for girth class $\mathrm{A}\left(1953.832 \mathrm{~kg} \mathrm{ha}^{-1} \mathrm{yr}^{-1}\right)$ in the uppermost soil depth (0-20 cm) while minimum FRP at $1.5 \mathrm{~m}$ distance was observed for girth class $\mathrm{A}\left(489.40 \mathrm{~kg} \mathrm{ha}^{-1} \mathrm{yr}^{-1}\right)$ and at $1 \mathrm{~m}$ distance for girth class B (488.08 $\left.\mathrm{kg} \mathrm{ha}^{-1} \mathrm{yr}^{-1}\right)$ in the lowermost soil depth $(40-60 \mathrm{~cm})$. Higher FRP in surface layer of soil corresponds to the higher nutrient availability due to high rates of litter accumulation and decomposition. Two way ANOVA at $5 \%$ level of significance, pointed 
out significant disparity in total fine root production between the sites $(F=8.87)$, between the soil depths $(F=129.56)$ while the impact on tree size $(F=0.08)$ and distance from tree base $(0.89)$ was reported to be insignificant [Table 3(a)].

\section{Fine Root Turnover rate $\left(\mathrm{yr}^{-1}\right)$}

Fine root turnover significantly varied across the sites $(F=12.45 ; p<0.05)$ and girth size $(F=5.54 ; p<0.05)$ while the effect of soil depth $(F=$ $0.62)$ and distance from tree base $(F=2.19)$ were insignificant [Table 3(a)]. The fine root turnover rate varied between 2.03 and $3.52 \mathrm{yr}^{-1}$ in $\mathrm{S} 1,1.93$ and 3.83 in $\mathrm{S} 2,2.75$ and $4.32 \mathrm{yr}^{-1}$ in S3, 1.77 and $4.24 \mathrm{yr}^{-1}$ in S4 at $1 \mathrm{~m}$ distance and at $1.5 \mathrm{~m}$ distance from tree base the FRT fluctuated between 1.74 and $3.37 \mathrm{yr}^{-1}$ in S1, 1.95and $3.33 \mathrm{yr}^{-1}$ in S2, 2.57 and $4.25 \mathrm{yr}^{-1}$ in S3, 1.77 and $4.16 \mathrm{yr}^{-1}$ in S4 (Fig.6). Distance from the tree bole and soil depth imparted positive impact on turnover rate.

\section{Discussion}

The architectural and functional aspects of the rooting system determine the survival of the trees (Christina et al. 2017). Fine root distribution in a particular area resonates with the nutrient availability within that ecosystem (Vitousek \& Sanford, 1986). Soil depth, canopy closure, density of the trees in the stand, aboveground biomass, site specific conditions and other management practices profoundly influence the FRB and FRT (Finer et al. 2011; Pie et al. 2018).

\section{Fine root biomass}

Across the investigated sites, the mean FRB ranged between 118.48 and $805.95 \mathrm{~kg} \mathrm{ha}^{-1}\left(0.11-0.80 \mathrm{Mg} \mathrm{ha}^{-1}\right)$ which was somewhat similar to the value (0.6-22.7 $\mathrm{Mg} \mathrm{ha}^{-1}$ ) reported for tropical broadleaf evergreen forests by Vogt et al. (1996) and Finer et al. (2011) but relatively lower (1.1-10.6 $\left.\mathrm{Mg} \mathrm{ha}^{-1}\right)$ than the value reported by Wen et al. (1999) and Yang et al. (2004) in world's subtropical forests and by Wang et al. (2017) in Chinese forests $\left(2.78 \mathrm{Mg} \mathrm{ha}^{-1}\right)$.Compared with agroforestry trees (78.39 and $\left.528.59 \mathrm{~kg} \mathrm{ha}^{-1}\right)$ of the bhabhar region as reported by Karki et al. (2021), the FRB of $S$. robusta was relatively higher.

In conformity to the earlier published reports (Upadhaya et al. 2005, Yuan et al. 2010) among all the four sites, fine root biomass reached its top notch value in the rainy season. These findings suggested that in subtropical and tropical forests highest FRB reported in the rainy season corresponds to periods of nutrients release. Yuan and Chen (2012) reported the role of soil microclimatic conditions in regulating intrannual fluctuations in FRB. Fine roots because of their morphological and anatomical properties have more prominent role in water absorption rather than nutrient absorption, thus water serves as a crucial factor in controlling FRB and FRP (Eissenstat \& Yanai, 2000). The FRB increased in the moist humid climate of the rainy season (July-September) during the study which corresponds to immediate rapid vegetative growth of the trees after summer induced dormancy due to hot and dry climate. Higher precipitation during the rainy season causes the soil to become rich in soil moisture content thus, increases the transport of nutrients from soil to the surface of roots which results in abundance of nutrients at superficial surface which leads to vigorous expansion and proliferation of root systems. Some other reports also supported our observation as according to them, fine root biomass wavered seasonally and fine root growth reached maximal limits during warm and moist months (Tierney et al. 2003; Kitajima et al. 2010). Arunachalam et al. (1996) and Sundarpandian \& Swamy (1996) observed the seasonal fluctuations in FRB in sub tropical and tropical forests and higher FRB was documented during moist and nutrient rich rainy season. However, FRB was not only linked to fine root growth but was also associated with fine root lifespan and FRT.

The results obtained for the vertical distribution of FRB were in accordance with findings of Karki et al. (2021a and b) Barbhuiya et al. (2012) in forest ecosystems and land use systems of Himalayan region which specifies the abundance of fine roots in upper layer of soil and decreased toward deeper soil $(40-60 \mathrm{~cm})$ in all the sites and seasons. Across all the sites and among all the seasons, the uppermost soil depth contributed (19.05-57.64\%) of total FRB, sub surface $(20-40 \mathrm{~cm}$ ) layer contributed (21.52-50.68\%) while,lowermost soil depth (40$60 \mathrm{~cm}$ ) contributed (22.10-50.50\%)(Fig. 7). Kaushal et al. (2019) and Maycock \& Congdon (2000) also elucidated that the topmost layer of soil is nutrient rich due to the release of nutrients from the litter which is responsible for ample fine root growth in uppermost layer of soil. In the present study, study sites varied in FRB in response to varying soil depth. Site S1 demonstrated highest depth related variation, having the highest slope value, whereas site S3 displayed lowest variation with minimum slope value (Fig.8).

The present study elucidates that nutrient availability in association with soil physical and chemical characteristics is one of the crucial factor that influences morphological and physiological aspects of tree fine roots (Yuan and Chen 2012). The horizontal distribution of FRB was similar to the trend reported by Karki et al (2021a). In all the sites, the FRB decreased with increasing distance from tree bole, with the highest FRB in the $1 \mathrm{~m}$ distance. 
The girth class usually correspond to the tree age i.e. girth size increases with increasing tree age as a result mature trees has higher girth size as compared to young trees. In this study, FRB showed a fluctuating trend; increased first and then decreased with increasing girth class (Fig. 9). Among all the sites, the higher FRB values were contributed by younger trees representing size classes $\mathrm{A}(43.38-54.94 \%)$ and C (43.22 - 61.23\%) during the rainy season as compared to older trees with size classes D (43.70-46.20\%) and E (35.27-56.54\%) (Fig.4). The greater proportion of fine root in small girth classes represents a strategy to produce more fine roots to increase absorption area for acquisition of resources and in turn, return organic matter to the soil to enhance plant growth. The age of the stand has a huge impact on FRB and generally, the younger stands possess more FRB in comparison to older stands (Claus and George (2005). Similar findings were reported by Pei et al (2018), while negative interaction among stand age and FRB was observed by Leuschner and Hertel 2003. Several studies conducted on FRB dynamics (Finer et al. 2011; Di Lorio et al. 2013) also reported that FRB was tremendously affected by tree age. The variation in FRB at different girth sizes in forest may be affected by several climatic and edaphic factors, stand density, canopy closure and management practices (Finer et al. 2011). During the initial years of planting, plants tend to absorb more nutrients and water for ample growth and development of above ground components thus, higher amount of nutrients are assigned to fine roots that brings about higher rate of production of fine roots with the progression of stand age that subsequently declines after reaching a maximum limit (Jagodzinski et al. 2016).

\section{Fine root production (FRP) and Fine root turnover (FRT)}

The current study estimated annual FRP within a range of $488-2483 \mathrm{~kg} \mathrm{ha}^{-1} \mathrm{yr}^{-1}$. Sites and soil depth influenced the annual FRP as annual FRP varied among the sites and decreased with the rise in the soil depth. Ford and Deans (1977) also reported similar trend of fine root allocation depthwise. Forest litter releases nutrients that govern and alter the production of fine roots (Cuevas and Medina 1988). Higher proportion of litter accumulated in the surface of the soil regulate the microclimatic conditions of the soil thus, provides an appropriate strata for growth and development of fine roots (Jordan and Escalante 1980). The FRP decreased with increasing distance from the tree stem. Among girth classes, highest FRP (2483.60 kg ha-1 $\left.\mathrm{yr}^{-1}\right)$ was reported for girth class C. Pei et al. (2018) and Yuan and Chen (2010) also reported that FRP first increase with increasing stand age to a peak and then declined towards old aged stands. The relationship of FRP with basal area (Helmisaari et al. 2007) is well established. However, tree age may negatively (Messier and Puttonen 1993), positively (Helmissari et al. 2002) affect the FRP or have no effect (Finer et al 2011). DBH also affects FRP positively (Li et al. 2003). Site characteristics and variability among species also serve as a key factor that shapes the FRP (Aerts et al 1992). The higher FRP in site S4 corresponds to the prominent tree density, elevated moisture content of the soil and nutrient - rich condition (high soil C and N) prevailing in this forest site (Table 1 and 2).

Fine root turnover tends to fluctuate with tree species composition, stand age as well as soil characteristics and plays a crucial role in determining the global $\mathrm{C}$ budget, nutrient flux forest ecosystems (Fonseca et al. 2012). The turnover rates reported in the experimental sites (2.03-3.52 $\left.\mathrm{yr}^{-1}\right)$ was relatively greater than the values $\left(0.4-2.8\right.$ year $\left.^{-1}\right)$ reported by Fukuzawa et al. (2013), McCormack et al. (2014) in fruit trees. Root turnover also varied across the sites and soil depth and the values reported surpassed the values reported in Himalayan Banj Oak and Chir Pine forests (Usman et al. 1999) and forests of Sweden (Persson 1983). Higher turnover rate might correspond to higher soil temperature as with the increase temperature upto a certain extent the microbial activities also increase which results in higher nutrient availability. In boreal forest ecosystems broad leaved species had higher FRT than needle leaved species (Yuan et al. 2010).

\section{Effects of soil characteristics on FRB, FRP and FRT}

Pearson's correlation test (Linear) was performed to determine the relationships between different soil parameters and fine root characteristics (Fig. 10). The result of the correlation matrix revealed that few soil parameters were highly correlated with each other expressing both negative and positive correlation while there was no correlation between certain studied variables. Soil depth showed strong negative correlation with FRB FRP, TN C: N ratio and porosity as these variables decreased with increasing soil depth while bulk density showed strong positive correlation with soil depth. Bulk density and porosity were negatively correlated with each other. FRB and FRP showed positive correlation with C:N ratio while FRP and FRT showed significant positive correlation with TN. Plants have a tendency of imparting more biomass to roots during the scarcity of resources in the environment as per the concept of optimal partitioning theory (Bloom et al. 1985). FRB is negatively while FRT is positively influenced by nitrogen content of the soil.

Soil pH showed negative correlation with FRB and FRP and positive correlation with FRT indicating that FRP is immensely affected by $\mathrm{pH}$ of the soil. Zhou et al. (2017) reported that acidic soils inhibit the microbial growth and activity thus, root growth can be stimulates in soils with a higher $\mathrm{pH}$. FRB and FRP showed strong positive correlation with porosity. Climatic, edaphic and geographical factors, determine the variations in FRB, FRP and FRT (Hendrick and Pregitzer, 1993; Pregitzer et al. 2000; Finer et al. 2011) as these are the major determinants regulating lifespan, survival and death of fine roots. The variations in soil characteristics among sites are related to space and time because of variations in topography, climate, weathering activities (Bargali et al. 1992 and 1993; Baumler and Zech 1994; Bargali et al.

Page 6/18 
2018). Baumler (2015) also stated that the soil characteristics frequently vary within the short distances in the region. FRT showed negative correlation with FRB and FRP (Fig 10).

\section{Conclusions}

The current study reported seasonal and depthwise variations in FRB, annual productivity and FRT in S. robusta along a gradient of tree girth size. The results showed that the effect of girth class size on FRB, FRP and FRT was significant but showed no clear trend with increasing girth class. The FRB showed high seasonal variation with highest FRB during rainy season and lowest during winter season. Temporally FRB and FRP declined as the depth and distance escalates. FRB, FRP and FRT were significantly affected by various soil characteristics resulting in significant differences among sites. For tree species, the fine roots absorb essential nutrients and water from the soil and return the nutrients back to the soil after death, the information reported on fine root production and turnover in $S$. robusta forest is of great ecological significance to plan, manage and execute practices to enhance productivity of sal forest ecosystem.

\section{Abbreviations}

KD: Kaladhungi; FP: Fatehpur; RB: Ranibagh; AP: Amritpur; FRB: Fine root biomass, FRP: Fine root production; FRT: Fine root turnover; A-E: Girth classes of S. robusta ; SD: Soil depth; WHC: water holding capacity; bD: bulk density; SM: Soil moisture; SOC: soil organic carbon; TN: total nitrogen; $\mathrm{C} / \mathrm{N}$ : Carbon and nitrogen ratio.

\section{Declarations}

\section{Funding}

The authors did not receive any financial support from any organization for the submitted work.

\section{Conflicts of interest / Competing interests}

The authors declare that they have no competing interests and no conflict of interest.

\section{Availability of data and material}

The dataset supporting the conclusions of this article is included in the article.

\section{Code availability}

Not applicable

\section{Author's contributions}

All authors contributed to the study conception and design. Data collection and preparation of first draft of the manuscript was done by RP. The manuscript was thoroughly modified and rectified by SSB and KB. After the preparation of final draft, all the authors read and approved the final manuscript and gave their consent for publication.

\section{Ethics approval}

Not applicable

\section{Consent to participate}

Not applicable

\section{Consent for publication}

Not applicable

\section{Acknowledgements}

We are thankful to the Head, Department of Botany for providing necessary lab facilities and we are highly grateful to the Divisional Forest Officer (DFO) Forest Department Division, Nainital for providing permission to conduct research work in Sal forests and to the Uttarakhand 
Tea Development Board, Bhawali, Nainital for the analysis of soil samples.

\section{References}

1. Aerts R, Bakker C, Caluwe H de (1992) Root turnover as determinant of the cycling of $\mathrm{C}, \mathrm{N}$ and $\mathrm{P}$ in a dry heathland ecosystem. Biochem 15:175-190

2. Anderson LJ, Comas LH, Lakso AN, Eissenstat DM (2003) Multiple risk factors in root survivorship: a 4-year study in concord grape. New Phytol 158(2):489-501. https://doi.org/10.1046/j.1469-8137.2003.00757.x

3. Arunachalam A, Pandey HN, Tripathi RS, Maithani K (1996) Biomass and production of fine and coarse roots during regrowth of a disturbed subtropical humid forest of north east India. Vegetatio 123:73-80. https://doi.org/10.1007/BF00044889

4. Baldi E, Toselli M, Eissenstat DM, Marangoni B (2010) Organic fertilization leads to increased peach root production and lifespan. Tree Physiol 30:1373-1382. https://doi.org/10.1093/treephys/tpq078

5. Barbhuiya AR, Arunachalam A, Pandey HN, Khan ML, Arunachalam K (2012) Fine root dynamics in undisturbed and disturbed stands of a tropical wet evergreen forest in northeast India. Trop Ecol 53:69-79

6. Bargali K, Manral V, Padalia K, Bargali SS, Upadhyay VP (2018) Effect of vegetation type and season on microbial biomass carbon in Central Himalayan forest soils, India. CATENA 171(12):125-135. 10.1016/j.catena.2018.07.001

7. Bargali SS (1996) Weight loss and N release in decomposing wood litter in a eucalypt plantation age series. Soil Biol Biochem 28:699702. 10.1016/0038-0717(95)00143-3

8. Bargali SS, Joshi M, Bargali K (1992) Seasonal pattern of total soil respiration in age series of eucalypt plantation and mixed broadleaved forest in Tarai belt of. Kumaun HimalayaOecologia 2:7-11

9. Bargali SS, Padalia K, Bargali K (2019) Effects of tree fostering on soil health and microbial biomass under different land use systems in central Himalaya. Land Degrad Dev 30(16):1984-1998. 10.1002/Idr.3394

10. Bargali SS, SinghRP, Joshi M (1993a) Changes in soil characteristics in eucalypt plantations replacing natural broad leaved forests. $J$ Veget Sci 4:25-28

11. Baumler R (2015) Soils In Nepal: An Introduction to the Natural History, Ecology and Human Environment in the Himalayas - A Comparison to the Flora of Nepal (eds Miehe, Pendry, C. A.), The Royal Botanical Garden, Edinburgh, p 125-134. https://doi.org/10.1080/00291951.2016.1202317

12. Bäumler R, Zech W (1994) Characterization of Andisols developed from non-volcanic material in eastern Nepal. Soil Sci 158:211-217

13. Black CA (1965) Methods of soil analysis. Academic press Inc.New York, p 369

14. Bloom AJ, Chapin FS, Mooney HA (1985) Resource limitation in plants-an economic analogy. Annu Rev Ecol Evol Syst 16:363-392. https://doi.org/10.1146/annur ev.es.16.110185.002051

15. Borja I, de Wit HA, Steffenrem A, Majdi H (2008) Stand age and fine root biomass, distribution and morphology in a Norway spruces chronosequence in southeast Norway. Tree Physiol 28:773-784. 10.1093/treephys/28.5.773

16. Christina M, Nouvellon Y, Laclau JP, Stape JL, Bouillet JP, Lambais GR, le Maire G (2017) Importance of deep water uptake in tropical eucalypt forest. Funct Ecol 31(2):509-519. doi:10.1111/1365-2435.1272

17. Cuevas E, Medina E (1988) Nutrient dynamics within Amazonian forests. II. Fine root growth, nutrient availability and leaf litter decomposition. Oecologia 76:222-235. https://doi.org/10.1007/BF00379956

18. Curt T, Lucot E, Bouchaud M (2001) Douglas-fir root biomass and rooting profile in relation to soils in a mid-elevation area (Beaujolais Mounts, France). Plant Soil 233:109-125. https://doi.org/10.1023/A:1010333308738

19. Di lorio A, Montagnolii A, Terzaghi M, Scippa GS, Chiatante D (2013) Effect of tree density on root distribution in Fagus sylvatica stands: a semi-automatic digitising device approach to trench wall method. Trees 27:1503-1513. 10.1007/s00468-013-0897-6

20. Eissenstat DM, Wells CE, Yanai RD, Whitbeck JL (2000) Building roots in a changing environment: implications for root longevity. New Phytol 147(1):33-42. https://nph.onlinelibrary.wiley.com/journal/14698137

21. Fahey TJ, Hughes JW (2004) Fine root dynamics in a northern hardwood forest ecosystem, Hubbard Brook Experimental Forest. J Ecol 82:533-548

22. Finer L, Ohashi M, Noguchi K, Hirano Y (2011) Factors causing variation in fine root biomass in forest ecosystems. For Ecol Manage 261:265-277. 10.1016/j.foreco.2010.10.016

23. Fonseca W, Alice FE, Rey-Benayas JM (2012) Carbon accumulation in aboveground and belowground biomass and soil of different age native forest plantations in the humid tropical lowlands of Costa Rica. New For 43(2):197-211. 10.1007/s11056-011-9273-9 
24. Ford ED, Deans JD (1977) Growth of Sitka spruce plantations: spatial distribution and seasonal fluctuations of lengths, weights and carbohydrate concentrations of fine roots. Plant Soil 47:463-485. https://doi.org/10.1007/BF00011504

25. Fukuzawa K, Shibata H, Takagi K, Satoh F, Koike T, Sasa K (2013) Temporal variation in fine-root biomass, production and mortality in a cool temperate forest covered with dense understory vegetation in northern Japan. For Ecol Manag 310:700-710. https://doi.org/10.1016/j.foreco.2013.09.015

26. Garkoti SC (2011) Fine root dynamics in three central Himalayan high elevation forests ranging from closed canopied to open canopied treeline vegetation. J For Res 16:136-143. 10.1007/s10310-010-0218-5

27. Gower ST, Vogt KA, Grier CC (1992) Carbon dynamics of Rocky Mountain Douglas-fir: influence of water and nutrient availability. Ecol Monogr 62:43-65. https://doi.org/10.2307/2937170

28. Hawkins BJ, Robbins S, Porter RB (2014) Nitrogen uptake over entire root systems of tree seedlings. Tree Physiol 34:334-342. https://doi.org/10.1093/treephys/tpu005

29. Helmisaari HS, Makkonen K, Kellomaki S, Valtonen E, Malkonen E (2002) Below- and above-ground biomass, production and nitrogen use in Scots pine stands in eastern Finland. For Ecol Manag 165:317-326. https://doi.org/10.1016/S0378-1127(01)00648-X

30. Helmisaari HS, Derome J, Nöjd P, Kukkola M (2007) Fine root biomass in relation to site and stand characteristics in Norway spruce and Scots pine stands. Tree Physiol 27:1493-1504

31. Hendrick RL, Pregitzer KS (1993) Patterns of fine root mortality in two sugar maple forests. Nature 361:59-61. https://doi.org/10.1038/361059a0

32. Indian Standard (1965) Part IV: grain size analysis. Indian Standard Institute, New Delhi, p 2720

33. Jackson ML (1958) Soil Chemical Analysis. Verlag: Prentice Hall, Inc. Englewood Clift, NJ. 498 S. DM, p 39-40. https://onlinelibrary.wiley.com/journal/15222624a

34. Jagodzinski AM, Ziolkowski J, Warnkowska A, Prais H (2016) Tree Age Effects on Fine Root Biomass and Morphology over Chronosequences of Fagus sylvatica, Quercus robur and Alnus glutinosa Stands. PLoS ONE 11(2): e0148668. doi:10.1371/ journal.pone.0148668

35. Jaramillo VJ, Hernandez RA, Kauffman JB (2003) Root biomass and carbon in a tropical evergreen forests of Mexico: changes with secondary succession and forest conversion to pasture. J Trop Ecol 19:457-464. https://www.jstor.org/stable/4092099

36. Jordan CF, Escalante G (1980) Root productivity in an Amazonian rain forest. Ecology 61:14-18. https://doi.org/10.2307/1937148

37. Karki H, Bargali K, Bargali SS (2021a) Spatial and Seasonal Pattern of Fine Root Biomass and Turnover Rate in Different Land Use Systems in Central Himalaya, India. Russian J Ecol 52(1):36-48. 10.1134/S1067413621010070

38. Karki H, Bargali K, Bargali SS (2021b) Spatial and Temporal Trends in Soil N-Mineralization Rates under the Agroforestry Systems in Bhabhar belt of Kumaun Himalaya. India. Agroforest Syst, (Accepted)

39. Kaushal R, Jayaparkash J, Mandal D, Kumar A, Alam NM, Tomar JMS, Mehta H, Chaturvedi OP (2019) Canopy management practices in mulberry: impact on fine and coarse roots. Agroforest Syst 93:545-556. 10.1007/s10457-017-0148-8

40. Konopka B, Noguchi K, Sakata T, Takahashi M, Konopkova Z (2007) Effects of simulated drought stress on the fine roots of Japanese cedar (Cryptomeria japónica) in a plantation forest on the Kanto Plain, eastern Japan. J For Res 12(2):143-151. https://doi.org/10.1007/s10310-006-0257-0

41. Kramer C, Trumbore S, Fröberg M, Cisneros Dozal LM, Zhang D, Xu X, Santos GM, Hanson PJ (2010) Recent (< 4 year old) leaf litter is not a major source of microbial carbon in a temperate forest mineral soil. Soil Biol Biochem 42:1028-1037. https://doi.org/10.1016/j.soilbio.2010.02.021

42. Kumar BM (2000) Ailanthus triphysa in the homegardens of Kerala, India: occurrence, basal area, average standing stock of wood and diameter structure. Indian J Agrofor 2:49-52

43. Leuschner C, Hertel D (2003) Fine root biomass of temperate forests in relation to soil acidity and fertility, climate, age and species. Prog Bot 64:405-438. https://doi.org/10.1007/978-3-642-55819-1_16

44. Li Z, Kurz WA, Apps MJ, Beukema SJ (2003) Belowground biomass dynamics in the Carbon Budget Model of the Canadian Forest Sector: recent improvements and implications for the estimation of NPP and NEP. Can J For Res 33:126-136. DOI:10.1139/x02-165

45. Litton CM, Ryan MG, Tinker DB, Knight DH (2003) Belowground and aboveground biomass in young postifrelodge pole pine forests of contrasting tree density. Can J For Res 33:351-363. doi:10.1139/X02-181

46. Lyubenova M (2009) Functional biocoenology. An - Di, Sofia, p 368

47. Majdi H, Ohrvik J (2004) Interactive effects of soil warming and fertilization on root production, mortality, and longevity in a Norway spruce stand in Northern Sweden. Global Change Biol 10:182-188. https://doi.org/10.1111/j.1365-2486.2004.00733.x

Page 9/18 
48. Maycock CR, Congdon RA (2000) Fine root biomass and soil N and P in North Queensland rainforests. Biotropica 32:185-190. https://www.jstor.org/stable/2663823

49. McCormack ML, Guo D (2014) Impacts of environmental factors on fine root lifespan. Front Plant Sci 5:1-11. https://doi.org/10.3389/fpls.2014.00205

50. Meinen C, Hertel D, Leuschner C (2009) Biomass and morphology of Wne roots in temperate broad-leaved forests diVering in tree species diversity: is there evidence of below-ground overyielding? Oecologia 161:99-111. https://dx.doi.org/10.1007\%2Fs00442-0091352-7

51. Messier C, Puttonen P (1993) Coniferous and non-coniferous fine-root and rhizome production in Scots pine stands using the ingrowth bag method. Silva Fenn 27:245-256

52. Misra R (1968) Ecology Workbook. Oxford and IBH Publishing Company, Calcutta

53. Noguchi K, Nagakura J, Konôpka B, Sakata T, Kaneko S, Takahashi M (2013) Fine-root dynamics in sugi (Cryptomeria japonica) under manipulated soil nitrogen conditions. Plant Soil 364:159-169. 10.1007/s11104-012-1354-9

54. Pei Y, Lei P, Xiang W, Ouyang S, Xu Y (2018) Effect of Stand Age on Fine Root Biomass, Production and Morphology in Chinese Fir Plantations in Subtropical China. Sustainability 10:22-80. https://doi.org/10.3390/su10072280

55. Persson HA (1983) The distribution and productivity of fine roots in boreal forests. Plant Soil 71:87-101. https://doi.org/10.1007/BF02182644

56. Piper CS (1950) Soil and Plant Analysis. The University of Adelaide.Academic press, New York

57. Pregitzer KS, King JS, Burton AJ, Brown SE (2000) Responses of tree fine roots to temperature. New Phytol 147:105-115. https://doi.org/10.1046/j.1469-8137.2000.00689.x

58. Raizada A, Jayaprakash J, Rathore AC, Tomar JMS (2013) Distribution of fine root biomass of fruit and forest tree species raised on old river bed lands in the northwest Himalaya. Trop Ecol 54(2):251-261

59. Schmid I, Kazda M (2002) Root distribution of Norway spruce in monospecific and mixed stands on diverent soils. For Ecol Manage 159:37-47. https://doi.org/10.1016/S0378-1127(01)00708-3

60. Singh JS, Singh SP (1992) Forests of Himalaya, Gyanodaya Prakashan, Naini Tal, pp 257

61. Subbiah BV, Asija GL (1956) A rapid procedure for the determination of available nitrogen in soil. Curr Sci 25:259-260

62. Sundarpandian SM, Swamy PS (1996) Influence of herbaceous species composition on fine roots biomass production in disturbed and undisturbed deciduous forests of Western Ghats in India. Acta Oecol 17:163-176

63. Tierney GL, Fahey TJ, Groffman PM, Hardy JP, Fitzhugh RD, Driscoll CT, Yavitt JB (2003) Environmental control of fine root dynamics in a northern hardwood forest. Glob Chang Biol 9:670-679. http://dx.doi.org/10.1046/j.1365-2486.2003.00622.x

64. Upadhaya K, Pandey HN, Law PS, Tripathi RS (2005) Dynamics of fine and coarse roots and nitrogen mineralization in a humid subtropical forest ecosystem of northeast India. Biol Fertil Soils 41:144-152. http://dx.doi.org/10.1007/s00374-004-0827-2

65. Usman S, Singh SP, Rawat YS (1999) Fine root productivity and turnover in two evergreen central Himalayan forests. Ann Bot 84:8794. 10.13140/RG.2.1.2332.9440

66. Vitousek P, Sanford L Jr (1986) Nutrient cycling in moist tropical forest. Annu Rev Ecol Syst 17:137. 10.1146/annurev.ecolsys.17.1.137

67. Vogt KA, Vogt DJ, Palmiotto PA, Boon P, O’Hara J, Asbjornsen H (1996) Review of root dynamics in forest ecosystems grouped by climate, climatic forest type and species. Plant Soil 187:159-219. https://www.jstor.org/stable/42947906

68. Walkley A, Black IA (1934) An examination of Degtjareff method for determining soil organic matter and the proposed modification of the chromic acid titration method. Soil Sci 37(1):29-38. 10.1097/00010694-193401000-00003

69. Wang S, Wang Z, Gu J (2017) Variation patterns of fine root biomass, production and turnover in Chinese forests. J For Res 28(6):1185-1194. http://dx.doi.org/10.1007/s11676-017-0386-7

70. Wen DZ, Wei P, Kong GH (1999) The productivity and turnover of fine roots of southern subtropical forests in Dinghu Mountains. Acta Bot Sin 23:361-369

71. Yang YS, Chen GS, Lin P, Xie JS, Guo JF (2004) Fine root distribution, seasonal pattern and production in four plantations compared with a natural forest in subtropical China. Ann For Sci 61:617-627. https://doi.org/10.1051/forest:2004062

72. Yuan ZY, Chen HYH (2010) Fine root biomass, production, turnover rates and nutrient contents in boreal forest ecosystems in relation to species, climate, fertility and stand age: Literature review and meta analysis. Cri Rev Plant Sci 29(4):204-221. https://doi.org/10.1080/07352689.2010.483579

73. Yuan ZY, Chen HYH (2013) Simplifying the decision matrix for estimating fine root production by the sequential soil coring approach. Acta Oecol 48:54-61. 10.1016/j.actao.2013.01.009 
74. Zhiyanski M (2014) Seasonal dynamics of fine root biomass in selected forest stands. Silva Balc 15:5-15

75. Zhiyanski M (2003a) Structure and biomass of the root system of Norway spruce (Picea abies Karst.) in the southwest Rila Mountain. Proceedings of Scientific Papers '75 years Forest Research Institute', BAS, pp 353-356

76. Zhou G, Zhou X, Zhang T, Du Z, He Y, Wang X, Xu C (2017) Biochar increased soil respiration in temperate forests but had no effects in subtropical forests. For Ecol Manag 405:339-349. https://doi.org/10.1016/j.foreco.2017.09.038

\section{Tables}

Table 1 Description of the Study Site

\begin{tabular}{|c|c|c|c|c|c|c|c|}
\hline Site & Locality & Latitude & Longitude & Elevation & $\begin{array}{l}\text { Tree density } \\
\text { (ind.ha }{ }^{-1} \text { ) }\end{array}$ & Dominant tree species & Table 2 Mean \\
\hline SITE -1 (S1) & Kaladhungi & $29^{\circ} 17^{\prime} 07.35^{\prime \prime} \mathrm{N}$ & $79^{\circ} 20^{\prime} 52.67^{\prime \prime} \mathrm{E}$ & $405 \mathrm{~m}$ & 630 & Shorea robusta & $\begin{array}{l}\text { values }( \pm \text { SE) of } \\
\text { the soil }\end{array}$ \\
\hline SITE-2 (S2) & Fatehpur & $29^{\circ} 19^{\prime} 23.69^{\prime \prime} \mathrm{N}$ & $79^{\circ} 18^{\prime} 05.34 " \mathrm{E}$ & $430 \mathrm{~m}$ & 620 & Shorea robusta & properties, under \\
\hline SITE-3 (S3) & Ranibagh & $29^{\circ} 17^{\prime} 10.03^{\prime \prime} \mathrm{N}$ & $79^{\circ} 32^{\prime} 49.19^{\prime \prime} \mathrm{E}$ & $580 \mathrm{~m}$ & 810 & Shorea robusta & four experimental \\
\hline SITE-4 (S4) & Amritpur & $29^{\circ} 17^{\prime} 54.32^{\prime \prime} \mathrm{N}$ & $79^{\circ} 32^{\prime} 44.11^{\prime \prime} \mathrm{E}$ & $575 \mathrm{~m}$ & 800 & Shorea robusta & $\begin{array}{l}\text { sites in S. } \\
\text { robusta forest }\end{array}$ \\
\hline
\end{tabular}

Table 3(a) F-Statistics and associated significance levels for the effect of sites, season, depth and distance from the tree base on fine root biomass, production and turnover in S. robusta.

\begin{tabular}{|llll|}
\hline Attributes & Variables (F value) & \\
\cline { 2 - 4 } & Fine root biomass (FRB) & $\begin{array}{l}\text { Fine root production } \\
(\text { FRP })\end{array}$ & $\begin{array}{l}\text { Fine root turnover } \\
\text { (FRT) }\end{array}$ \\
\hline Sites(Si) & $16.04^{\star}$ & $8.87^{*}$ & $12.45^{\star}$ \\
\hline Soil depth(Sd) & $71.58^{\star}$ & $129.56^{*}$ & 0.62 \\
\hline Girthclass(GC) & $7.21^{\star}$ & 0.08 & 5.64 \\
\hline Distance(D) & 1.03 & 0.89 & 2.19 \\
\hline Season(Se) & $197.86^{*}$ & - & - \\
\hline
\end{tabular}

*Significant, $p<0.05$

Table3(b) Effect of sites, season, girth class, distance and soil depth on FRB

${ }^{*} p<0.001$

\section{Figures}




\begin{tabular}{|c|c|c|c|c|c|c|c|c|c|c|}
\hline Sites & SD & Texture & WHC (\%) & $\begin{array}{l}\mathrm{bD} \\
\left(\mathrm{gcm}^{-3}\right)\end{array}$ & $\mathrm{pH}$ & SM (\%) & $\begin{array}{l}\text { POROSITY } \\
(\%)\end{array}$ & SOC (\%) & TN (\%) & $\mathrm{C} / \mathrm{N}$ \\
\hline \multirow[t]{4}{*}{ S1 } & $\begin{array}{l}0- \\
20\end{array}$ & $\begin{array}{l}\text { Clay } \\
\text { Loam }\end{array}$ & $54.57 \pm 0.02$ & $1.21 \pm 0.04$ & $5.87 \pm 0.11$ & $12.37 \pm 2.23$ & $53.62 \pm 1.70$ & $1.20 \pm 0.21$ & $0.18 \pm 0.01$ & $9.63 \pm 0.49$ \\
\hline & $\begin{array}{l}20- \\
40\end{array}$ & Clay & $58.24 \pm 0.44$ & $1.30 \pm 0.01$ & $5.80 \pm 0.09$ & $14.83 \pm 1.91$ & $50.09 \pm 0.35$ & $1.23 \pm 0.42$ & $0.16 \pm 0.01$ & $10.68 \pm 2.67$ \\
\hline & $\begin{array}{l}40- \\
60\end{array}$ & Clay & $58.48 \pm 2.73$ & $1.39 \pm 0.03$ & $5.70 \pm 0.11$ & $13.49 \pm 1.97$ & $46.52 \pm 1.10$ & $1.48 \pm 0.31$ & $0.12 \pm 0.01$ & $5.06 \pm 0.68$ \\
\hline & \multicolumn{2}{|c|}{ Mean } & $57.09 \pm 1.06$ & $1.31 \pm 0.08$ & $5.79 \pm 0.10$ & $13.56 \pm 2.03$ & $50.07 \pm 1.05$ & $1.30 \pm 0.31$ & $0.15 \pm 0.01$ & $8.45 \pm 1.25$ \\
\hline \multirow[t]{4}{*}{ s2 } & $\begin{array}{l}0- \\
20\end{array}$ & Loam & $44.79 \pm 0.97$ & $1.21 \pm 0.03$ & $7.11 \pm 0.16$ & $8.36 \pm 1.02$ & $53.40 \pm 1.09$ & $1.84 \pm 0.19$ & $0.22 \pm 0.02$ & $9.12 \pm 0.80$ \\
\hline & $\begin{array}{l}20- \\
40\end{array}$ & $\begin{array}{l}\text { Clay } \\
\text { loam }\end{array}$ & $43.36 \pm 1.65$ & $1.34 \pm 0.02$ & $7.15 \pm 0.13$ & $9.65 \pm 1.46$ & $48.31 \pm 0.66$ & $2.03 \pm 0.15$ & $0.20 \pm 0.02$ & $8.78 \pm 0.46$ \\
\hline & $\begin{array}{l}40- \\
60\end{array}$ & Loam & $46.58 \pm 2.62$ & $1.44 \pm 0.05$ & $6.92 \pm 0.14$ & $11.83 \pm 1.73$ & $44.69 \pm 1.96$ & $1.47 \pm 0.27$ & $0.19 \pm 0.02$ & $6.28 \pm 0.79$ \\
\hline & \multicolumn{2}{|c|}{ Mean } & $44.91 \pm 1.74$ & $1.33 \pm 0.03$ & $7.06 \pm 0.14$ & $9.94 \pm 1.40$ & $48.8 \pm 1.23$ & $1.78 \pm 0.20$ & $0.20 \pm 0.02$ & $8.06 \pm 0.68$ \\
\hline \multirow[t]{4}{*}{ S3 } & $\begin{array}{l}0- \\
20\end{array}$ & $\begin{array}{l}\text { Clay } \\
\text { loam }\end{array}$ & $43.81 \pm 1.15$ & $1.26 \pm 0.02$ & $7.40 \pm 0.17$ & $9.46 \pm 0.83$ & $51.57 \pm 0.81$ & $1.65 \pm 0.11$ & $0.23 \pm 0.03$ & $10.35 \pm 2.9$ \\
\hline & $\begin{array}{l}20- \\
40\end{array}$ & $\begin{array}{l}\text { Clay } \\
\text { loam }\end{array}$ & $51.42 \pm 2.20$ & $1.30 \pm 0.02$ & $7.41 \pm 0.16$ & $9.04 \pm 2.05$ & $49.83 \pm 0.79$ & $1.37 \pm 0.10$ & $0.23 \pm 0.04$ & $8.61 \pm 1.88$ \\
\hline & $\begin{array}{l}40- \\
60\end{array}$ & $\begin{array}{l}\text { Clay } \\
\text { loam }\end{array}$ & $43.11 \pm 0.40$ & $1.41 \pm 0.03$ & $7.67 \pm 0.07$ & $14.07 \pm 1.90$ & $45.65 \pm 1.09$ & $1.32 \pm 0.19$ & $0.17 \pm 0.01$ & $5.59 \pm 0.22$ \\
\hline & \multicolumn{2}{|c|}{ Mean } & $46.11 \pm 1.25$ & $1.32 \pm 0.07$ & $7.49 \pm 0.4$ & $10.85 \pm 1.59$ & $49.01 \pm 0.89$ & $1.44 \pm 0.13$ & $0.21 \pm 0.02$ & $8.18 \pm 1.59$ \\
\hline \multirow[t]{4}{*}{ S4 } & $\begin{array}{l}0- \\
20\end{array}$ & $\begin{array}{l}\text { Clay } \\
\text { loam }\end{array}$ & $40.94 \pm 0.84$ & $1.06 \pm 0.01$ & $5.50 \pm 0.20$ & $16.09 \pm 2.19$ & $59.15 \pm 0.09$ & $2.87 \pm 0.11$ & $0.28 \pm 0.06$ & $11.93 \pm 1.38$ \\
\hline & $\begin{array}{l}20- \\
40\end{array}$ & $\begin{array}{l}\text { Clay } \\
\text { loam }\end{array}$ & $43.55 \pm 2.14$ & $1.30 \pm 0.06$ & $5.42 \pm 0.14$ & $11.77 \pm 1.19$ & $49.92 \pm 2.50$ & $2.74 \pm 0.31$ & $0.26 \pm 0.04$ & $11.80 \pm 1.71$ \\
\hline & $\begin{array}{l}40- \\
60\end{array}$ & $\begin{array}{l}\text { Clay } \\
\text { loam }\end{array}$ & $45.32 \pm 2.22$ & $1.40 \pm 0.03$ & $5.31 \pm 0.09$ & $11.58 \pm 0.74$ & $46.35 \pm 1.06$ & $2.62 \pm 0.23$ & $0.22 \pm 0.03$ & $11.55 \pm 1.84$ \\
\hline & \multicolumn{2}{|c|}{ Mean } & $43.27 \pm 1.73$ & $1.25 \pm 0.03$ & $5.41 \pm 0.14$ & $13.14 \pm 1.37$ & $51.80 \pm 1.21$ & $2.74 \pm 0.21$ & $0.25 \pm 0.04$ & $11.76 \pm 1.6$ \\
\hline
\end{tabular}

Page 12/18 


\begin{tabular}{|c|c|c|c|c|c|c|c|c|c|}
\hline \multirow[t]{3}{*}{ Pairs } & \multirow[t]{3}{*}{ Paired Dimension } & \multicolumn{7}{|c|}{ Paired samples t-test (Two- tailed) } & \multirow{3}{*}{$\begin{array}{l}\text { Significant } \\
\text { (p) }\end{array}$} \\
\hline & & \multirow[t]{2}{*}{ Mean } & \multirow[t]{2}{*}{$\begin{array}{l}\text { Standard } \\
\text { deviation } \\
\text { (SD) }\end{array}$} & \multirow[t]{2}{*}{$\begin{array}{l}\text { Standard error } \\
\text { mean (SEM) }\end{array}$} & \multicolumn{2}{|c|}{$\begin{array}{l}99 \% \text { confidence interval } \\
\text { of the difference }\end{array}$} & \multirow[t]{2}{*}{$\mathrm{t}$} & \multirow[t]{2}{*}{ df } & \\
\hline & & & & & Lower & Upper & & & \\
\hline $\begin{array}{l}\text { Pair } \\
1\end{array}$ & $\begin{array}{l}\text { Site- Fine root } \\
\text { Biomass }\end{array}$ & -270.63 & 164.98 & 5.02 & -283.58 & -257.67 & -53.90 & 1079 & $.000 *$ \\
\hline $\begin{array}{l}\text { Pair } \\
2\end{array}$ & $\begin{array}{l}\text { Season-Fine root } \\
\text { biomass }\end{array}$ & -271.13 & 165.18 & 5.02 & -284.10 & -258.16 & -53.94 & 1079 & $.000 *$ \\
\hline $\begin{array}{l}\text { Pair } \\
3\end{array}$ & $\begin{array}{l}\text { Girth c lass- Fine } \\
\text { root Biomass }\end{array}$ & -270.13 & 164.85 & 5.01 & -283.07 & -257.18 & -53.84 & 1079 & $.000 *$ \\
\hline $\begin{array}{l}\text { Pair } \\
4\end{array}$ & $\begin{array}{l}\text { Distance-Fine root } \\
\text { biomass }\end{array}$ & -271.63 & 164.85 & 5.01 & -284.57 & -258.68 & -54.14 & 1079 & $.000 *$ \\
\hline $\begin{array}{l}\text { Pair } \\
5\end{array}$ & $\begin{array}{l}\text { Soil depth- Fine } \\
\text { root biomass }\end{array}$ & -271.13 & 165.15 & 5.02 & -284.10 & -258.16 & -53.95 & 1079 & $.000 *$ \\
\hline
\end{tabular}

\section{Figure 1}

Location map of the experimental sites

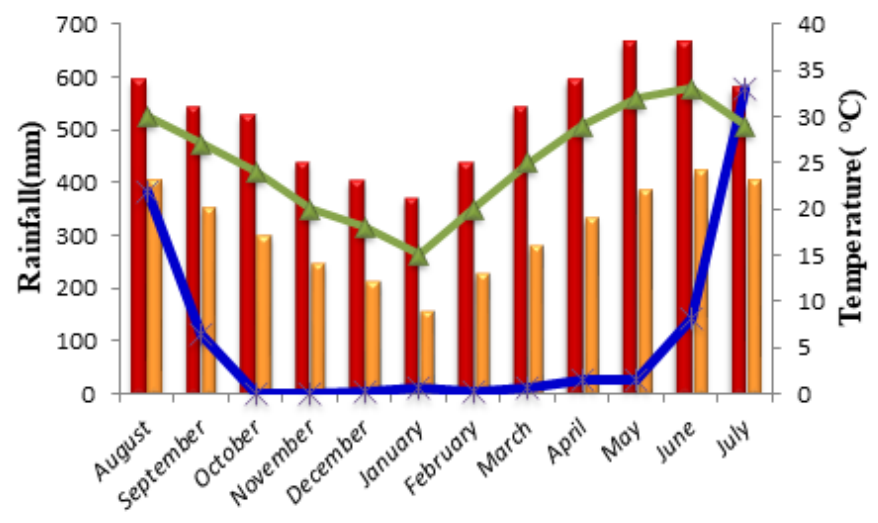

Figure 2

Climatic data for the year 2017-2018 

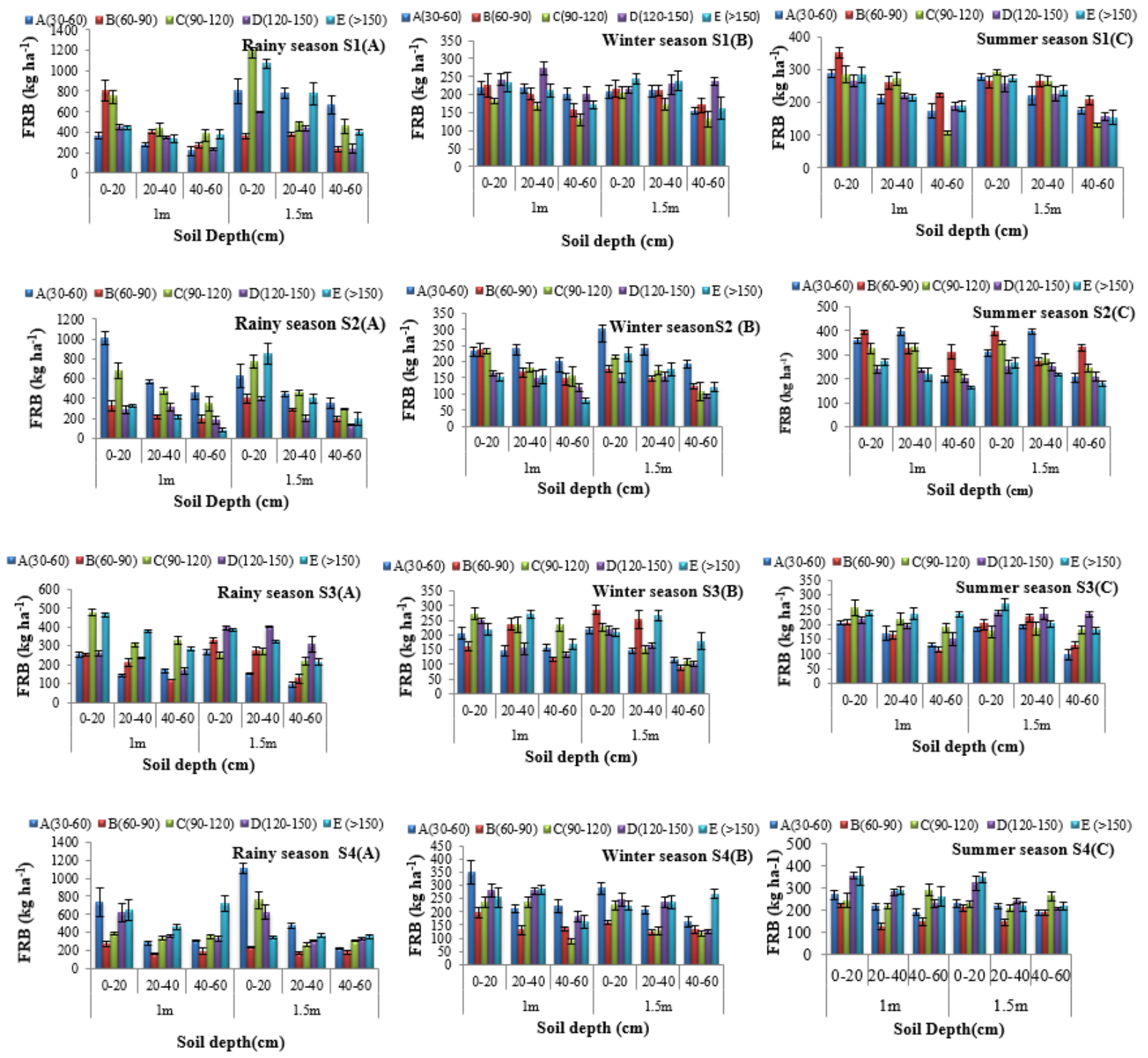

\section{Figure 3}

Temporal variations in fine root biomass in relation to tree size, soil depth and distance from tree base across the experimental sites (S1S4) [A-E: Girth classes of S. robusta (cm), FRB: Fine root biomass] 

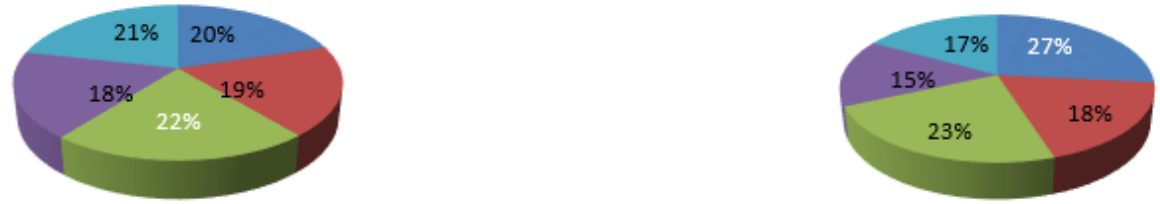

$\|\mathrm{A}(30-60 \mathrm{~cm})=\mathrm{B}(60-90 \mathrm{~cm})=\mathrm{C}(90-120 \mathrm{~cm})=\mathrm{D}(120-150 \mathrm{~cm})=\mathrm{E}(>150)\| \mathrm{A}(30-60 \mathrm{~cm})\|\mathrm{B}(60-90 \mathrm{~cm})\| \mathrm{C}(90-120 \mathrm{~cm})\|\mathrm{D}(120-150 \mathrm{~cm})\| \mathrm{E}(>150)$

S3 (c)
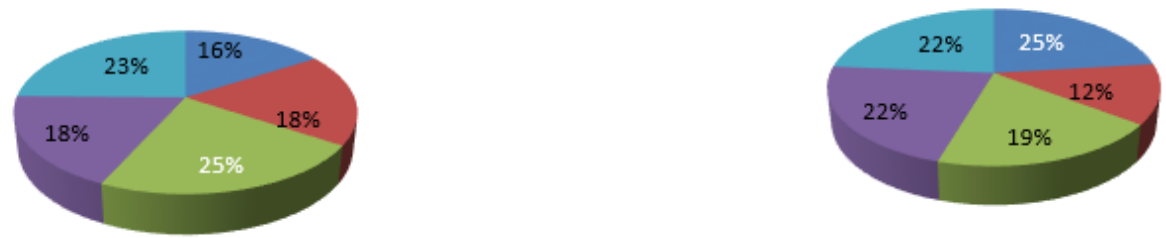

\section{Figure 4}

Percent biomass contribution by different girth classes in the studied sites
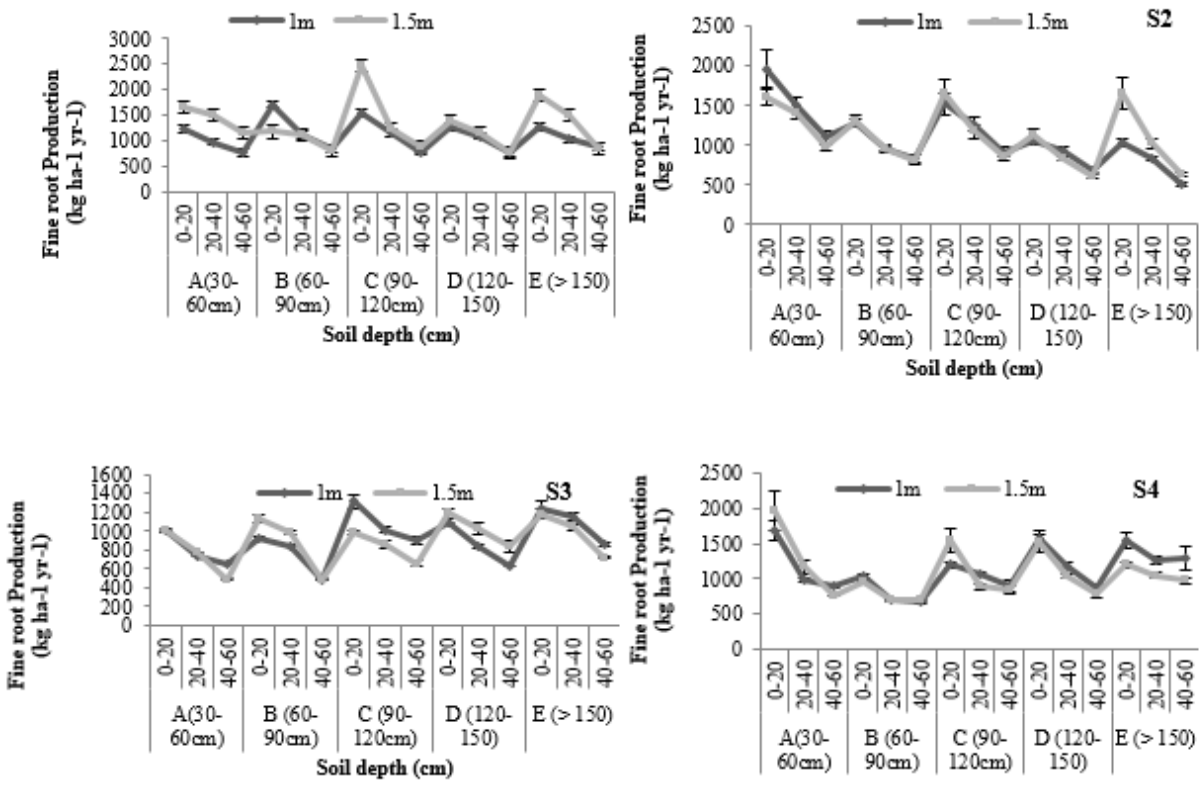

Soil depth (cm)

\section{Figure 5}

Spatial variability in fine roots production across the experimental sites 

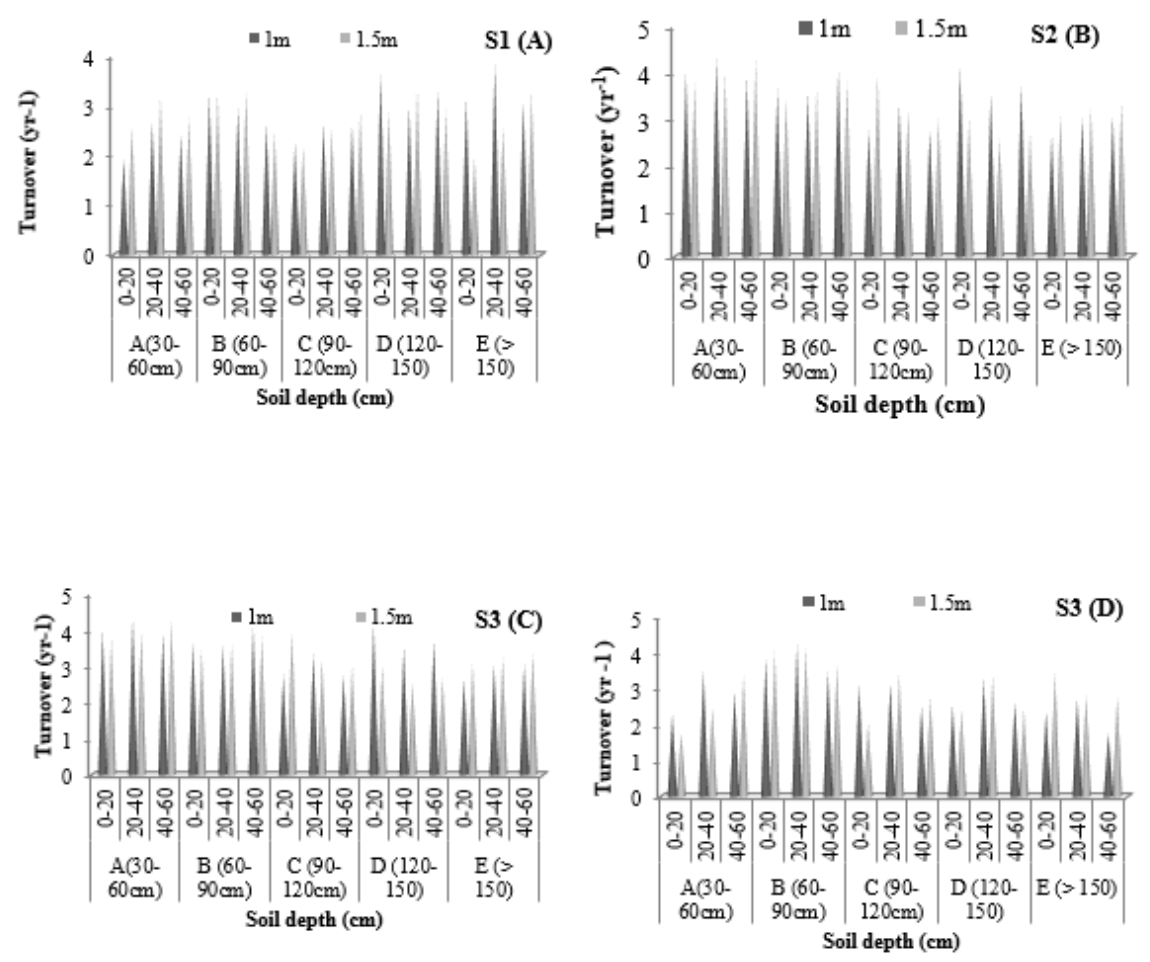

\section{Figure 6}

Spatial variations in fine root turnover (yr-1) across the experimental sites (S1-S4)
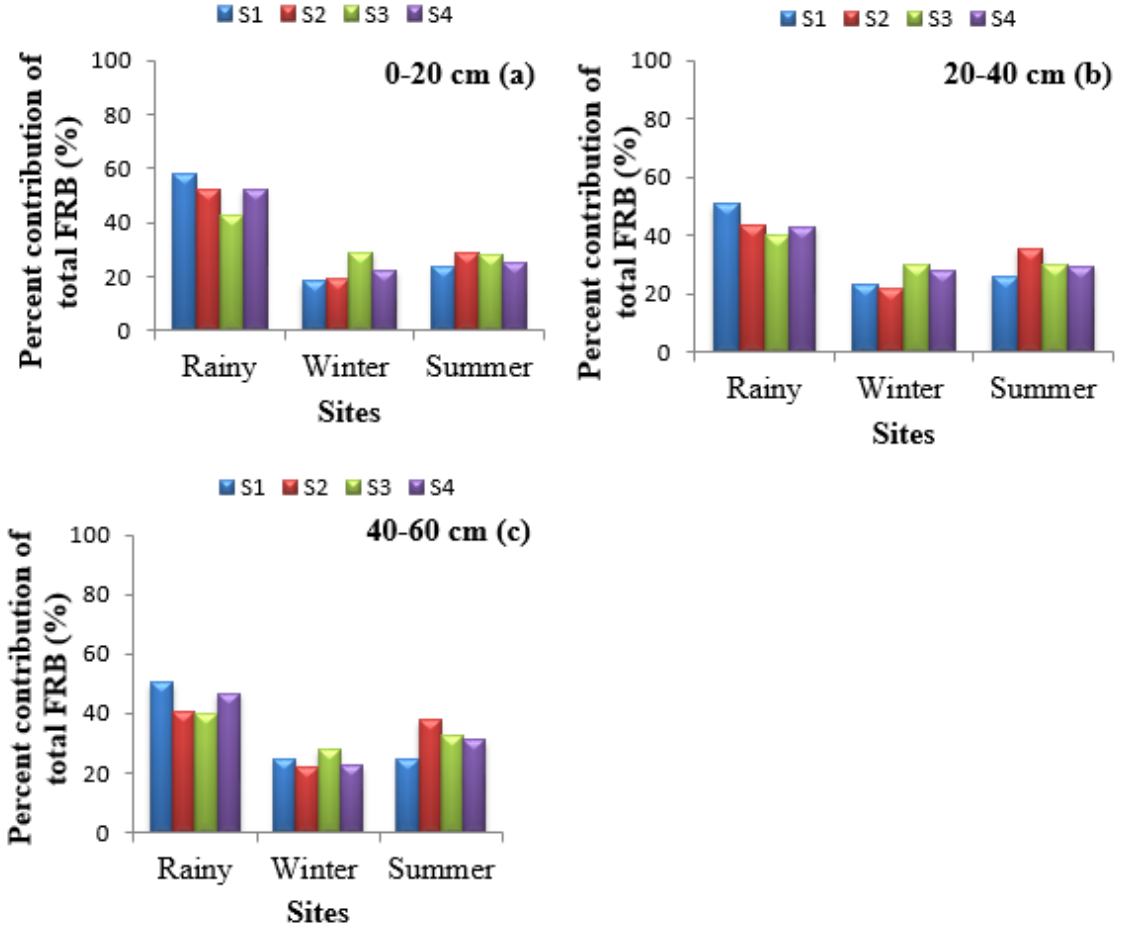

Figure 7

Depthwise percent Contribution of fine root biomass across the seasons and sites (a-c) 


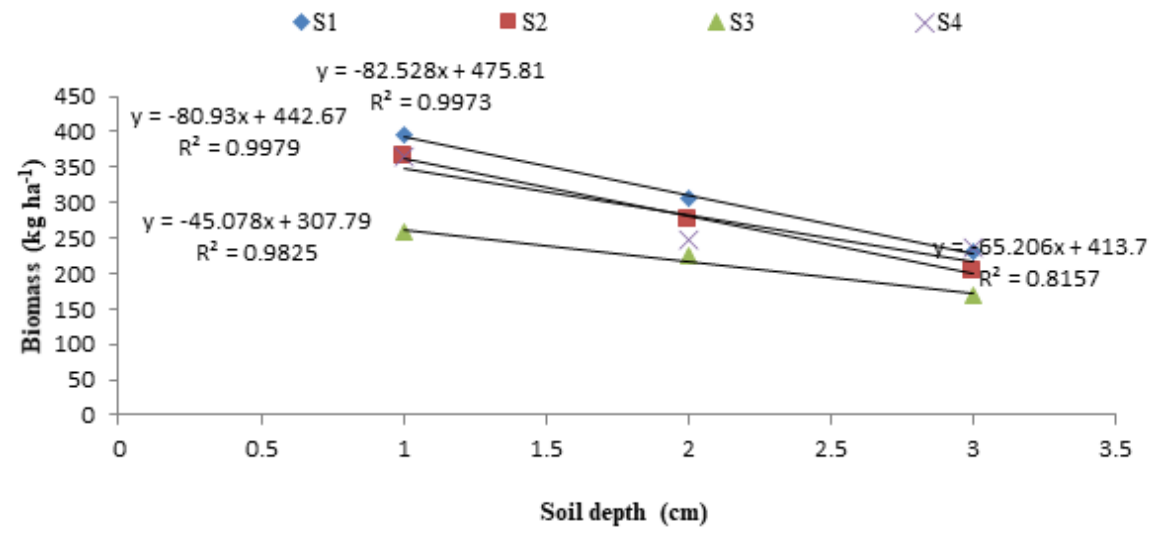

Figure 8

Regression analysis showing relationship between soil depth and fine root biomass
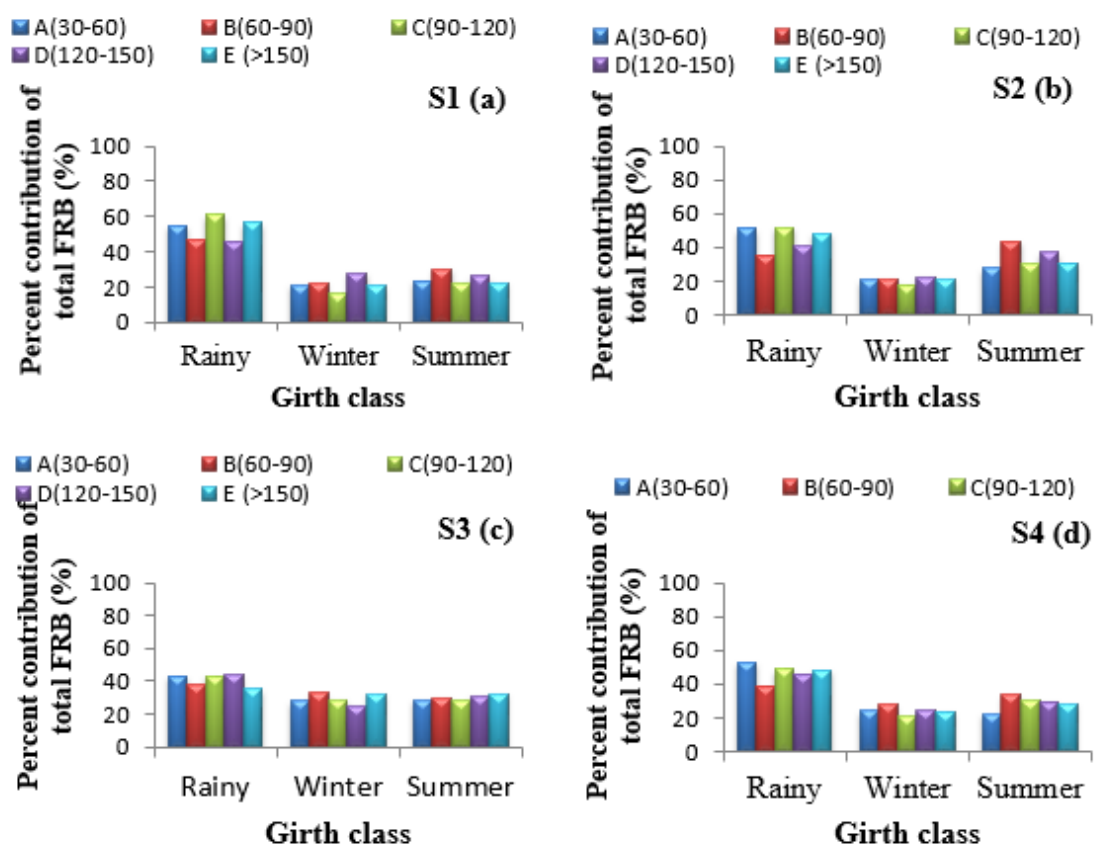

\section{Figure 9}

Girth wise seasonal variations in fine root biomass across the study sites (S1-S4)

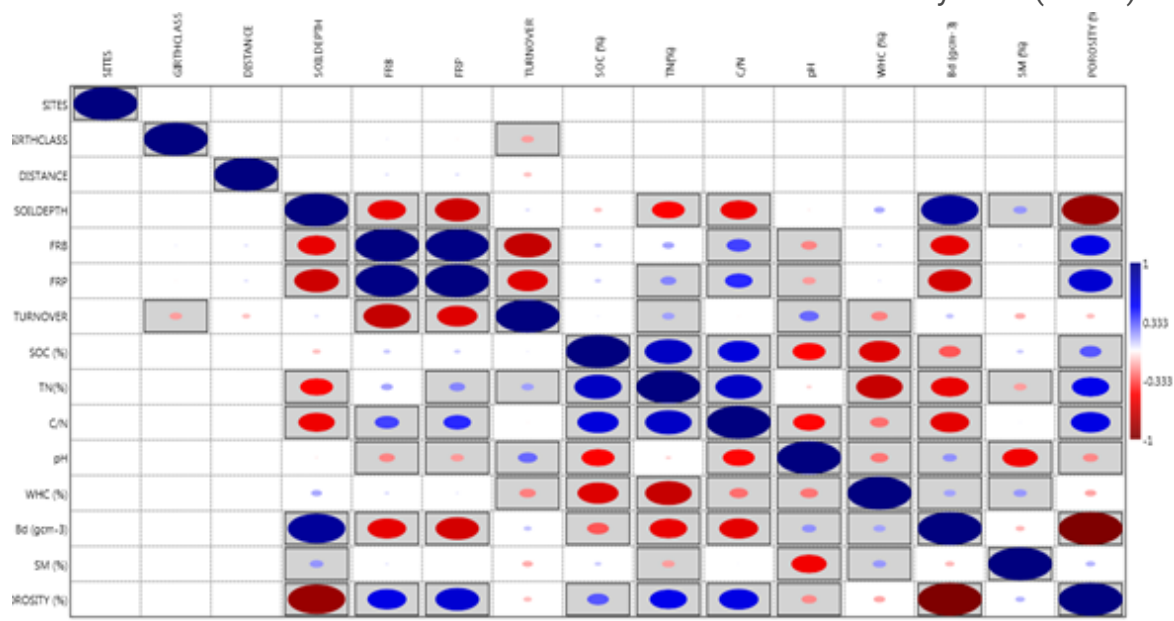




\section{Figure 10}

Correlation matrix of the soil and fine root parameters; more visible circles shows higher correlation among variables; bluish color indicated positive correlation while reddish color indicated negative correlation. FRB-Fine root biomass, FRP-Fine root production, SOC-soil organic carbon, TN-total nitrogen, C/N-Carbon and Nitrogen ratio, WHC-Water holding capacity, bD-bulk density, SM-Soil moisture [Boxes show significant values $(\mathrm{p}<0.05)]$ 